\title{
Assessment of Available Feed Resources in Damot Sore Woreda, Wolaita Zone, Southern Ethiopia
}

\author{
Debebe Ayele, Abaynesh Anjulo, Senait Adaro and Asrat Ayza
}

\begin{abstract}
This study was conducted in Damot Sore Woreda, Wolaita Zone, Southern Nation Nationalities and People Regional State with the objective of assessing available feed resources in the area. Eighty households, 40 from Woinadega and 40 from Qolla were selected randomly. A semi-structured questionnaire was prepared and an interview was carried out to collect data. The major feed resources available in the study area included; natural pasture, crop residues, agro-industrial by-products and some improved forages like Elephant grass, pigeon pea, Guatemala, (Desho were described. The major feeding systems practiced in the area were free grazing, rotational grazing, zero grazing/cut and carry systems, tethering and herding together. The major feed production constraints forwarded by the farmers include shortage of grazing land lack of improved forage seed and lack of awareness about conservation of feeds during periods of high availability, less extension work on interventions of feed shortage through improved forage development although some efforts were made by the bureau of agriculture and nongovernmental organization. In general feed conservation in the form of silages and hay, supplementations of tree legumes and treatments of crop residues should be practiced to alleviate feed shortage and boost livestock productivity.
\end{abstract}

Keywords: Availability, Damot Sore; Feed resource, Improved Forages.

DOI: $10.7176 /$ RHSS/11-17-01

Publication date:September $30^{\text {th }} 2021$

\section{INTRODUCTION}

Ethiopia has the largest livestock inventories in Africa estimated at about 54 million heads of cattle, 25.5 million head of sheep, 24.06 million of goats. From the total cattle population $98.95 \%$ are local breeds and the remaining are hybrid and exotic breeds (CSA, 2013). This sector has a significant contribution to the country's economy and still expected to support its economic development. However, the contribution of the sector to individual income and national economy at large is below its potential (Solomon, 2010).

The livestock subsector currently support and sustain livelihood for $80 \%$ of all rural population. Despite high livestock population and existing favorable environmental condition, the current livestock output of the country is little. This is associated with a number of complex and inter-related factors such as inadequate feed and nutrition, wide spread diseases, poor genetic potential of local breeds and in efficiency of livestock development services with respect to credit extension, market and infrastructure (Solomon etal.,2003).

The majority of available livestock feed resource in Ethiopia are natural pasture, crop residues, agro-industrial by products and some improved forages. The first two contribute the largest share in small holder livestock production system (Alemayehu, 2003).

Under smallholder livestock production system, animals are dependent on a variety of feed resources which vary both in quality and quantity which is the most important factor in affecting either positively or negatively the potential of animals. For optimum livestock productivity, the available feed resource should match with the number of animal in a given area. It is well established that poor nutrition and feed shortages are the main factors for the poor performance of livestock in Ethiopia (Adugna, 2007).

Damot Sore Woreda is one of the livestock production potential Districts of Wolaita zone which is rich both in different feed resources and improved forages. However, there is scarcity of information regarding this issue though the contribution is high for livestock production. Therefore, this study was designed to assess available feed resources in the area.

\section{MATERAIAL AND METHODS}

\subsection{Description of the study area}

Damot Sore Woreda is found in Wolaita zone, SNNPR, located at 398 kilometers South West of Addis Ababa. The Woreda is situated at $7^{0} 35^{\prime}$ ' longitude and $38^{0} 1^{\prime}$ ' latitude with an altitude ranges between 1300-2200 meter above sea level and mean annual rainfall ranges from 820 millimeter up to 1200 millimeter. The mean annual maximum and minimum temperature of the area is 22 and $13 \mathrm{c}^{0}$ respectively (DSWAO, 2010).

\subsection{Sampling technique}

The Woreda has two agro-ecologies namely; Woinadega and Qolla. From each agro-ecology two Kebeles were selected based on feed production potential. A total of 80 households were selected using simple random sampling methods. Group discussions were made with local leaders (Kebele) and model farmers. An interview was made 
using semi-structured questionnaire to collect data on the type of feed resources, type of improve forages, grazing land size, agricultural by-products, crop residues and other non-conventional feed resources.

\subsection{Data Collection}

Data was obtained from both primary and secondary sources. Primary data was collected through interview using questionnaires and personal observation. The secondary data was obtained from written documents, agricultural offices and other sources.

\subsection{Data Analysis}

The data collected was analyzed using simple descriptive statistics such as frequencies, means, percentages, etc.

\section{RESULT AND DISCUSSION}

\subsection{Household characteristics}

The majority (61.3\%) of households were male headed and (38.7\%) females in the studied area. The average age of household head was 45.6 years. Out of the households included in the current study, about $23.8 \%$ Illiterate, 41.3\% Elementary education completed and the rest accounted for about $18.7 \%$ were Junior, $10 \%$ High school and $6.2 \%$ above High school respectively. The average family size of the surveyed households was 5.7 persons per household (Table 1).

Table1: Household characteristics of the respondents

\begin{tabular}{|c|c|c|}
\hline Variables & $(\mathrm{N}=\mathbf{8 0})$ & $\%$ of respondents \\
\hline \multicolumn{3}{|l|}{ Sex of the household head } \\
\hline Males & 49 & 61.3 \\
\hline Females & 31 & 38.7 \\
\hline \multicolumn{3}{|l|}{ Educational status } \\
\hline Illiterate & 19 & 23.8 \\
\hline Elementary & 33 & 41.3 \\
\hline Junior & 15 & 18.7 \\
\hline High school & 8 & 10 \\
\hline Above high school & 5 & 6.2 \\
\hline Age of the household head & 80 & $45.6 \pm 1.12$ \\
\hline Average family size per household & & $5.7 \pm 0.23$ \\
\hline
\end{tabular}

$\mathrm{N}=$ Number of respondents

\subsection{Land holding per household}

Table 2 indicated the average size of land holding per household and the use pattern of the area. The average total land holding per household in the study area was 0.88 ha and the minimum and maximum land holding is 0.02 to $0.52 \mathrm{ha}$, respectively per household.

Table 2: Land holding and use pattern

\begin{tabular}{lll}
\hline Land use pattern & Household (ha) & \% of total \\
\hline Crop land & 0.521 & 59 \\
Homestead & 0.067 & 7.6 \\
Grazing land & 0.153 & 17.3 \\
Fallow and wood land & 0.121 & 13.7 \\
Forage production & 0.021 & 2.4 \\
Average total land holding & 0.883 & 100 \\
\hline
\end{tabular}

In the current study, larger land holding was allocated for cereal crop production (59\%) like maize, wheat, teff, barley, pulse crops like hair coat bean are contributing larger proportion for household food and income generation. The crop residues obtained as by-products of these crops were playing significant role in supplying seasonal feed resources for the animals.

Grazing land (Private gazing and communal grazing areas) were the major sources of animal feed. Communal grazing areas are decreasing from time to time and many individuals are relying on improving private gazing areas than communal areas. Cultivation of grazing land for farm land is another factor for the decrement of the grazing areas in the district.

The land allocated for forage production area $(2.4 \%)$ is relatively too small as compared to crop land. This reality is true in many parts of the country as well. As result the browse feeds contributing the dry season feed were declining and animals with browsing nature are depending on other feeds. 


\subsection{Available feed resources and Feeding system identified}

Feeds

Animal feeds represent the major input for any production systems. Respondents in the study area indicated that available feed resources for livestock came from different sources as follows.

\section{Natural Pasture}

Natural pasture is the most common feed resources for all livestock species in the study area. From the total respondents $(50 \%)$ use natural pasture mainly and only $(30 \%)$ of the respondents feed natural pasture with hay in the study area. Peoples their cattle to the grassland were naturally grown grasses, shrubs, herbs during morning and turn back during night.

Table 3: Natural pastures used in the study area

\begin{tabular}{lll}
\hline Natural pastures & \multicolumn{2}{c}{$\%$ of respondents } \\
\cline { 2 - 3 } & Woinadega $(\mathrm{N}=40)$ & Qolla $(\mathrm{N}=40)$ \\
Grass & 73 & 74 \\
Legumes & 7 & 7 \\
Herbs & 15 & 16 \\
Shrubs & 5 & 3 \\
\hline
\end{tabular}

\section{Crop Residues}

\section{$\mathrm{N}=$ Number of respondents}

Crop residues are the main feed resources in the study area. Some of those crop residues mainly used in the study area were maize and sorghum Stover, wheat, teff, and barely straw were the major crop residues as shown in Table 4 below.

Table 4: Crop residues used in the study area

\begin{tabular}{lcl}
\hline Crop residues & \multicolumn{2}{c}{$\%$ of respondents } \\
\cline { 2 - 3 } & Woinadega(N=40) & Qolla(N=40) \\
Maize Stover & 33 & 37 \\
Sorghum Stover & 2 & 6 \\
Teff straw & 35 & 42 \\
Wheat straw & 13 & 6 \\
Barely straw & 17 & 9 \\
\hline
\end{tabular}

$\mathrm{N}=$ Number of respondents

Agro-industrial by products

Agro-industrial by products are feed sources from milling industry, brewery industry, local distillers like "atela" of Areka and "tella", household feed wastes and others which had major role in increasing livestock productivity in the area as shown in table 5 below.

Table 5: Agro-industrial by products used in the study area

\begin{tabular}{llc}
\hline Agro-industrial by products & \multicolumn{2}{c}{$\%$ of respondents } \\
\cline { 2 - 3 } & Woinadega $(\mathbf{N}=\mathbf{4 0})$ & Qolla( $\mathbf{N = 4 0})$ \\
Wheat bran & 45 & 41 \\
Wheat short & 13 & 13 \\
Malt calm & - & - \\
Molasses & - & - \\
Nouge cake & 15 & 13 \\
Atela & 27 & 33 \\
\hline
\end{tabular}

$\mathrm{N}=$ numbers of respondents

\section{Cultivated forages}

Improved grasses have better productivity, palatability and nutrient characteristics that make them desirable for inclusion in improved forage production programs (Alemayehu, 2002). Improved legume forages species provide suitable source of protein and improves the productivity of the animals. Cultivated forages are mainly important as cut and carry system and source of feed and as supplement to crop residues and natural pasture. Elephant and Desho grasses are among the grass species and the herbaceous legumes are examples of cultivated forages (Agajie et al., 2002). 
Table 6: Cultivated forages used in the studied areas

\begin{tabular}{lcc}
\hline Forage types & \multicolumn{2}{c}{$\%$ of respondents } \\
\hline & Woinadega $(\mathbf{N}=\mathbf{4 0})$ & Qolla(N=40) \\
Elephant grass & 27 & 28 \\
Rhodes grass & 3 & 7 \\
Desho grass & 18 & 19 \\
Oats & 3 & 1 \\
Vetches & 5 & 1 \\
Alfalfa & 4 & 6 \\
Sesbania & 7 & 8 \\
Cow pea & 7 & 1 \\
Pigeon pea & 1 & 3 \\
Desmodium & 5 &
\end{tabular}

\section{Sources of Improved forage}

$\mathrm{N}=$ number of respondents

The sources of improved forage in the study area were presented in (Table 7). The higher proportion of households used improved forages for their livestock feed supply from NGO project is (45\%). Most of the improved forage species (palris, Elephant grass and pigeon pea) introduced by RCBDI, (Guatemala, Desho, Elephant grass) by Send cow project (Desho and elephant grass) by district bureau of agricultural office. The respondent farmers had better awareness about improved forages because of repeated and sustainable training and demonstration was made by the bureau of agriculture and NGOs. However, the adoption pattern is very limited mainly because of the shortage of forage seeds at regional and national level. Cultivated forage and pasture crops are grown as nursery, back yard system as a live fence and in soil water conservation sites.

The reports of CSA (2008) indicated that improved forages are very few in coverage, which is not more than $1 \%$ at country level. This indicates most of the farmers are either not well aware of about the benefit of the improved forages or adoption due to land shortage because priority is given for food crops. Alemayehu and Sisay (2003) also reported that forage development approaches were started long years ago however, the adoption level is not encouraging. This does not mean that low efforts were made for introduction and follow up of the adoption process of the improved forages. For example, ministry of agriculture (MOA) started forage innovations and interventions starting at early 1980s through second, third and fourth livestock development projects.

Table 7: Sources of improved forage in the study area

\begin{tabular}{lcc}
\hline Sources of improved forage & $\mathbf{( N = 8 0 )}$ & \% of respondents \\
\hline Local farmer & 13 & 16.2 \\
Neighbor (purchased) & 6 & 7.5 \\
Market (purchased) & 3 & 3.8 \\
State farm(purchased) & 23 & 28.7 \\
NGO project & 35 & 43.8 \\
\hline
\end{tabular}

\section{Concentrates}

$\mathrm{N}=$ number of respondents

Concentrates is a feed or a feed mixture which supplies protein, carbohydrate and fat at high level but contains $<18 \%$ of crude fiber with low moisture. It can be from home made and purchased from the market. It consists of relatively large quantity of a major feed constituent in the study area as shown table 8 below.

Table 8: Supplements given to lactating cows in the studied area

\begin{tabular}{lcl}
\hline Concentrates & \multicolumn{2}{c}{ \% respondents } \\
\cline { 2 - 3 } Cereal & Woinadega $(\mathbf{N}=\mathbf{4 0})$ & Qolla $(\mathbf{N}=\mathbf{4 0})$ \\
Maize & 45 & 52.5 \\
Sorghum & 17.5 & 22.5 \\
Cotton seed & 2.5 & 7.5 \\
Home made & 7.5 & 10 \\
\hline
\end{tabular}

\section{Feeding systems}

$\mathrm{N}=$ Number of respondents

Feeding systems are practiced in the studied area are free grazing, rotational grazing, zero grazing/cut and carry systems, tethering and herding together was practiced in the area as shown Table 9 below. 
Table 9: Major feed sources and feeding system identified in the area

\begin{tabular}{lcc}
\hline Feeding system & \multicolumn{2}{c}{$\%$ of respondents } \\
\cline { 2 - 3 } Free grazing & Woinadega(N=40) & Qolla $(\mathbf{N}=\mathbf{4 0})$ \\
Rotation grazing & 65 & 75 \\
Zero grazing & 13.5 & 17 \\
Tethering \& herding & 6 & 3 \\
together & 15.5 & 5 \\
\hline
\end{tabular}

$\mathrm{N}=$ Number of respondents

\subsection{Constraints of feed production}

Feed shortage both in quality and quantity is among the major livestock production and productivity problems. Constraints of livestock feed production identified in the studied are shown in Table 10.

Table 10: Constraints to livestock feed production in the study area

\begin{tabular}{lcc}
\hline Constraints & \multicolumn{2}{c}{$\%$ of respondents } \\
\cline { 2 - 3 } Shortage of grazing land & Woinadega(N=40) & Woinadega(N=40) \\
Lack of improved forage (seed) & 67 & 65 \\
Lack of awareness on feed conservation & 23 & 19 \\
Low extension & 7 & 11 \\
\hline
\end{tabular}

The major feed availability constraints forwarded by the farmers and other livestock holders during group discussion time include shortage of grazing land, lack of improved forage seed and lack of awareness about conservation of feeds during periods of high availability, less extension work on interventions of feed shortage through improved forage development although some efforts were made by the bureau of agriculture and nongovernmental organization. The nature of the problems varies among different areas. However, Woliata being highly populated zone in the region, crowded population influenced for the fast decrement size of the grazing lands, from which year round feed is coming.

\section{CONCLUSION AND RECOMMENDATION}

According to the present findings, the major feed resources available to livestock production in the study Woreda such as natural pasture, crop residues, agro-industrial by-products and different concentrates were identified and improved forages grown in the area were described. About $50 \%$ of the feed resources identified available for livestock production in the area was natural pasture followed by crop residue (42\%). Most of the improved forage species produced in the Woreda included; Elephant grass, Pigeon pea, Guatemala (Desho). The major feeding systems practiced in the studied area were free grazing, rotational grazing, zero grazing/cut and carry systems, tethering and herding together. The major constraints feed production identified included shortage of grazing land, lack of improved forage seed and lack of awareness about conservation of feeds during periods of high availability, less extension work on interventions of feed shortage through improved forage. Based on the findings, feed conservation in the form of silages and hay should be practiced, plantations of improved forage should be increased to improve feed availability both in quantity and quantity and treatments of crop residues should be practiced in the area.

\section{REFERENCES}

Adugna, T., 2009 Livestock feed supply situation in Ethiopia. Commercialization of Livestock Agriculture in Ethiopia: Proceedings of the $16^{\text {th }}$ annual conference of the Ethiopian Society of Animal Production (ESAP) held in Addis Ababa, Ethiopia, October 8 -10, 2008. Part I: Plenary Session. P.O. Box 80019, Addis Ababa, Ethiopia.

Adugna, T., Alemu Y., and Alemu D. (2012): Livestock feed resources in Ethiopia: Challenges, Opportunities and the need for transformation. Ethiopia Animal Feed Industry Association, Addis Ababa, Ethiopia.

Adugna, T., Said, A. N., 1994. Assessment of feed resources in Wolaita Sodo. Ethiopian jounal of Agricultural Sciences. Vol. 14 (1/2). Pp.69-87

Adugna, T.,(2007). Feed resource for producing export quality meat and livestock in Ethiopia example from selected woredas in Oromia and SNNP Regional states, Ethiopia.

Alemayehu, M., and Sissay A., 2003. Integrated Livestock Development Project (ILDP). Livestock Feed Resources Survey. North Gondar, Ethiopia.pp. 75

Alemayehu, M., 1985. Feed resources in Ethiopia. Apaper presented at a workshop on animal feed resources for small scale livestock procedures.11-15 November, 1985, Nirobi, Kenya. Livestock improvement conference. IAR, Addis Ababa, Ethiopia. pp. 143-146 
Alemu Y., Zinash S.; Seyoum B., 1991. The Potential of Crop Residues and Agro-Industrial By-Products as Animal Feed.In: ESAP Proceedings, Third National Livestock Improvement Conference.24-26 May 1989.Addis Ababa, Ethiopia.pp57-63

Anderson, F.M. (1985): Draught animal power systems in Sub-Saharan Africa.Their productivity impact and research needs. Proceedings of International workshop held at james cook

Ashagre, A., 2008. Effect of Nitrogen Fertilizer and harvesting stage on yield and quality of natural pasture in Fogera district, North western Ethiopia. An MSc. thesis submitted to the School of Graduate studies Haramaya University.94p.

Assefu, G., 2012.Comparative Feedlot Performance of Washera And Horro sheep fed different roughage to concentrate ratio. An MSc. thesis submitted to the school of graduate studies Haramaya University.129p.

Asrat A, Ayele A, and Milkias K. (2015), Dairy Cattle Production systems in HumboWoreda, Wolaita Zone, Southern Ethiopia. Journal of Biology, Agriculture and Health care vol.5,13 pp.

Banerje, G.C., 1998. A textbook of animal husbandry $8^{\text {th }}$ edition, Oxford and 1 BH publishing Co.PVT. LTD. NEW Delhi, Calcutta, India. 1079p.

Berhanu, G., H. Adane and B. Kahsay (2009). Feed marketing in Ethiopia: Results of rapid market appraisal. Improving Productivity and Market Success (IPMS) of Ethiopian farmers project Working Paper 15. ILRI(International Livestock Research Institute), Kenya.www.fao.org/fileadmin/templates/agphome/.../wk2 c6 gerard.pdf.

Beyene, T. (2009). Assessment of livestock feed resource and feeding system in Assosa zone, Benshangul-Gumuz region, Ethiopia. MSC thesis Hawassa University, Ethiopia central statistics Agency 2010 Report on small scale manufacturing industries survey. Statistical Bullet in 480. Addis Abeba, Ethiopia.

Birhanu (2009). The contribution of crop residues reached up to $50 \%$ to the nutritional basis of livestock in Ethiopia mixed farming system.

Central statistical Agency (CSA) 2008.Ethiopian statistical Abstract, Centeral statistical Authority, Addis Abeba, Ethiopia.

CSA (2013). Agricultural sample survey, 2012/13 (2005 E.C), volume ii: Report on livestock and livestock characteristics (privet peasant holdings). Statistical Bullet in 570 central statistical Agency (CSA), Federal Democratic Republic of Ethiopia, Addis Abeba.

DSWAO (Damot sore woreda Agricultural Office) (2010). Unpublished Agro-ecological data of the woreda.

ELDMPS (Ethiopian livestock Development masters plan study). 2007. livestock Development master plan study. Volume I- Dairy. Government of Ethiopia, ministry of Agriculture and rural development.

FAO ( Food and Agricultural organizations), 1997 Roughage utilization in Warm climate. In FAO Animal production and animal health paper $135 \mathrm{p}$.

John M. and Siegfried D. (1987): Forage Network in Ethiopia News Letter on Utilization of Crop Residues and Agro- industrial by-products with special emphasis on technologies applicable to small scale African farmers. February 5-6, International livestock centre for Africa. Addis Ababa, Ethiopia. pp .5-11

Kidane, G., 1993 Effect of cutting date on botanical composition and nutritive value of native pasture in central highlands of Ethiopia. An MSC thesis presented to Haremaya University, Ethiopia.

Solomon G, 2010 Sheep and goat production and marketing system in Ethiopia. International livestock institute, Addis Ababa.

Solomon, B., Solomon, M. and Alemu Y., 2008. A potential use of crop residues as livestock feed reduces under small holder farmers conditions in Bale high lands of Ethiopia. Tropical and subtropical Agro-ecosystems, 8 (1) : 107-114.

Welearegay H. (2012), Challenges and opportunities of milk production underdifferent urban dairy farm sizesin Hawassa City, Southern Ethiopia

Yayneshet, T., 2010. Ethiopia Sanitary \& Phytosanitary Standards and Livestock and Meat Marketing Program (SPS-LMM) Texas A\&M University System:Feed Resources 99 Availability in Tigray Region, northern Ethiopia, for Production of Export Quality Meat and Livestock.

Yeshitila, A., Tessema, Z. and Azage, T. 2008. Availability of livestock feed resources in Alaba woreda, Sothern Ethiopia. In : proceeding of the $16^{\text {th }}$ annual conference of the Ethiopian society of animal production (ESAP) held in Addis Ababa Ethiopia, October 8 to 10, 2008.

Yigrem S, Beyene F, Tegegne A and Gebremedhin B. 2008. Dairy production, processing and marketing systems of Shashemene-Dilla area, South Ethiopia.

Zinash, S., Seyoum, B., Lulseged, G. and Tadesse, T., 1995. Effect of harvesting stage on yield and quality of natural pasture in the central highlands of Ethiopia. PP. 316-322. In :proceedings of the Ethiopian Society of Animal Production (ESAP); Third National Conference 27-29 April 1995. IAR, Addis Ababa, Ethiopia. 